\title{
Metafore sebstva u autobiografskom diskursu Vesne Parun
}

Kornelija Kuvač-Levačić*

klevac@unizd.hr
UDK: 821.163.42 Parun, V.

82-94:159.9

Izvorni znanstveni rad / Original scientific paper

Primljeno: 14. travnja 2016.

Prihvaćeno: 9. lipnja 2016.

Služeći se konceptom sebstva kao cjelokupnosti ljudske osobnosti, kako je to definirao Carl Gustav Jung i produbio P. Ricoeur (teorija narativnog identiteta, sebstvo definirano kao identitet konstruiran narativnom konfiguracijom, dijalektika otkrivanja drugoga u vlastitom sebstvu i vlastitoga sebstva u drugome), u radu će se analizom metafora koje izriču sebstvo autodijegetskog pripovjedača istražiti model stvaranja autobiografskog diskursa Vesne Parun. Osnovu obrađenog korpusa činit će tekstovi iz zbirke Noć za pakost. Moj život u 40 vreća (2001.). Iz prvog poglavlja zbirke [što ga čine ranije objavljeni autoričini autobiografsko-esejistički tekstovi: Poljubac života (1993.), Do zalaska sunca hodajući za kamilicom (1958.), Pod muškim kišobranom (1986.)] čitatelj doznaje da je pisanje autobiografije za autoricu bilo problem samoizricanja pa je taj čin neprestano odgađala, dok je, s druge strane, osjećala snažan unutrašnji poriv da to ipak učini. Ta paradoksalnost autoričine motivacije ogleda se i u nekima od konstitutivnih elemenata koje pratimo u njezinu autobiografskom diskursu. $U$ odnosu književnosti i zbilje, koju sam žanr autobiografije propituje na poseban način, autorica naglašeno stvara odmak od pukog dokumentarnog prenošenja zbiljskih činjenica iz svoga života. To se odražava u negiranju kronološkog niza ispripovijedanih događaja u korist kolažne i fragmentarne organizacije teksta, zatim u naglašenom lirizmu koji mjestimice negira odnos »metafora kao sredstvo književnosti« i pretvara ga u odnos »književnost kao metafora«. Autobiografski diskurs Vesne Parun gusto je prepleten metaforikom za mnoge od kojih se može zaključiti da izražavaju njezino sebstvo. Trima metaforama se u ovom radu daje posebna pozornost - kišobranu, koji može biti »muški« $i \gg z ̌ e n s k i \ll$, zemljovidu, koji na zidu ima svaka kuća u Vesninu zavičaju, te vreći, koju prati

\footnotetext{
* Doc. dr. sc. Kornelija Kuvač-Levačić, Odsjek za hrvatski jezik i književnost, Odjel za kroatistiku i slavistiku Sveučilišta u Zadru, Obala kralja Petra Krešimira IV., HR-23000 Zadar.
} 
simboličan broj 40, u koliko ih je stao čitav njezin život. Osim spomenutih metafora, u radu će se ispitati teza da se u autobiografskom diskursu Vesne Parun sama književnost predstavlja kao ključna metafora njezina sebstva, čime se isti taj diskurs čitatelju otkriva kao izrazito (auto)metatekstualan.

Ključne riječi: sebstvo, autobiografizam, narativni identitet, Vesna Parun, metafora, kišobran, zemljovid, vreća.

\section{Uvod}

Istraživanje metafora sebstva u autobiografskom diskursu odnosi se prvenstveno na njegovu funkciju samoizražavanja i propitkivanja subjekta teksta kao autora. Govoreći o statusu autobiografskog teksta kroz povijest njegova istraživanja, Friederike Eigler obrazlaže kako je došlo do shvaćanja da se u samom temelju autobiografskog diskursa zapravo nalazi iskustvo subjekta kao ljudskog bića, pozivajući se na studiju Jamesa Olneya Metaphors of Self (1972). Iz iste studije F. Eigler egzemplarnim izdvaja mišljenje da sve autobiografije upućuju na »jedan subjekt, jedan motiv iza svih ljudskih nastojanja na bilo kojem području: upravo iskustvo ljudskog bića «. ${ }^{1}$ Za predmetno je istraživanje značajna Olneyeva teza da prizvati sjećanje, biti svjestan i povećavati svjesnost, stvoriti svoju metaforu, znači živjeti. J. Olney čin nastajanja autobiografije uspoređuje s nastojanjem čovjeka da se ostvari kao cjelina, u smislu konstruiranja cjelokupnog ljudskog iskustva koje naziva Simboličkim Čovjekom, da se vrati svojoj prvobitnoj cjelovitosti (koja je u mitskoj svijesti izgubljena izgonom iz Edena), a to je u sadašnjem ljudskom stanju moguće izvesti samo na sintetičkoj ili simboličkoj razini. ${ }^{2}$ Tako je svaki ostvaraj pojedinačnog ljudskog iskustva u nekom autobiografskom tekstu zapravo vlastita autorova metafora za Čovjeka. ${ }^{3}$

Istraživanjem metafora sebstva u autobiografskom diskursu Vesne Parun ispitat ćemo funkcioniranje Olneyeve usporedbe o eksperimentatoru koji promatra cjelinu eksperimentator-eksperiment, ali i samoga sebe u stanju promatranja, i tako dalje unedogled, ili do onog idealnog stanja pune i savršene samosvjesnosti gdje postoji svjesnost potpunog sebe, tjelesnog i duhovnog, instinktivnog i voljnog. ${ }^{4}$ Da bismo produbili poznavanje odnosa između naracije i konstitiuiranja/izražavanja sebstva, a radi otvaranja novih perspektiva čitanja autobiografskog diskursa V. Parun, dotičemo se istraživanja hermeneutike sebstva Paula Ricœura koje je provodila J. Brnčić. Sebstvo je ondje definirano kao

\footnotetext{
${ }^{1}$ Friederike EIGLER, O statusu autobiografskog teksta, Kolo, 2 (2002), www.matica.hr/ kolo/289/O\%20statusu\%20autobiografskog\%20teksta/ (20.04.2016).

2 Prema: James OLNEY, Metaphors of Self. The Meaning of Autobiography, Princeton, Princeton University Press, 1972, 318.

${ }^{3}$ Usp. isto, 321.

${ }^{4}$ Usp.isto, 331, prema Eigler, nav. dj.
} 
identitet što ga može oblikovati tek dinamika narativne konfiguracije, pri čemu, dakako, on ne može biti sveden na narativni identitet, ${ }^{5}$ ali iz njega proizlazi, on ga konstituira. Sebstvo nam nije dano, nego ga zadobivamo posredstvom priča, te nas stoga »književnost može osloboditi od redukcionističkog, narcisoidnog ega «, od egologije, filozofskoga imperijalizma jastva. ${ }^{6}$ Književnost nas otvara drugosti, a bez drugosti nema ni spoznaje sebstva, ${ }^{7}$ što se vidi iz činjenice da Ricœur poziva na narativnu interpretativnu praksu kadru uspostavljati uzajamne odnose između dva pola: istosti i drugosti, otvarajući time put mogućnosti otkrivanja drugoga $u$ našem sebstvu i naše sebstvo $u$ drugome. ${ }^{8}$ Osim toga, subjekt se ni ne može spoznati trenutačno i izravno, nego je nužan neizravan, zaobilazan pristup subjektivnoj svijesti. Subjekt, zapravo, nije konstitutivan ni za svijet niti za samoga sebe. Naprotiv, sav je sazdan od znakova. ${ }^{9}$ Za njegovu fenomenologiju dijade sebstvo-drugost karakterističan je hermeneutički pluralizam drugosti, stanovita "polisemija drugosti« koja ide od našega iskustva vlastite svijesti i tijela, preko našega iskustva drugih osoba, živih ili mrtvih (predaka) sve do odnosa prema božanskome, živome ili odsutnome. ${ }^{10}$

\footnotetext{
${ }^{5}$ U Ricœurovoj knjizi Temps et récits III (1985.) narativni identitet opisan je kao identitet što ga čitatelji grade u susretu s tekstovima koje tumače, a u Soi-même comme un autre (1990.) kao osobni identitet koji proizlazi iz samotumačenja, tj. iz tumačenja sebstva konstituirana poput priče [prema: Jadranka BRNČIĆ, Ricœurova hermeneutika sebstva, Filozofska istraživanja, 28 (2008) 3, 731-747. http://hrcak.srce.hr/index.php?show=clanak\&id_clanak_jezik=57635].

${ }^{6}$ Usp. Brnčić, nav. dj., 735.

${ }^{7}$ I filozof Emanuel Levinas, primjerice, u knjizi Totalitet $i$ beskonačnost (Beograd, NK Jasen, 2006.) i u Drukčije od bivstva ili s onu stranu bivstvovanja (Otherwise Than Being or Beyond Essence, Boston, Dordrecht, Kluwer Academic Publishers, 1991.) strukturu sebstva tumači odnosom Ja-Drugi. Sebstvo je uvijek otvoreno blizini, uvijek pozvano na odgovor, uvijek adresirano Drugim, a da pri tom nije samoorijentirano. O Levinasovu konceptu sebstva čitamo u radu E. Obučića koji navodi da »egocentrična samokoncepcija subjekta adekvatno ne objašnjava formaciju odnosa, jer ne uzima u obzir prvenstvo osobe koja je prva na sceni. Kada se prvenstvo prvog na sceni uzme u razmatranje, budući da prethodi svijetu sa kojim se identifikujem i koji konstituišem, tada blizina budi sopstvo iz samozainteresovanog spektakla i ograničenog samoposmatranja. Buđenje iz svijeta namijenjenog samo meni, zbog svoje dubine, predstavlja tešku traumu za sam ego koja, prethodeći svijesti, ukazuje egu da nije koncipiran kao radikalno samoprisustvo, kao singularno ja, već kao sopstvo raščlanjeno na blizinu Drugog i drugačijeg. Prema Levinasovoj definiciji blizine, umjesto geometrijske distance, riječ je o subjektu koji se približava svojim privilegovanim prvenstvom u svijetu. Ovo približavanje je starije od a priornosti, prethodi stvaranju, te dovodi u pitanje lični egoizam i samoprisustvo. Biti stariji od a priornosti znači da Drugi uslovljava i oblikuje cjelokupno iskustvo sopstva konstituišući time njegove etičke koordinate. Raščlanjeno blizinom Drugog, iskustvo sopstva više nije singularno, već odnosno. « [Engin OBUČIĆ, Levinas. Blizina koja konstituiše, Diskursi, 1 (2011) 1, www. diskursi.com/uploads/2011/10/58_pdfsam_001_CASOPIS+DISKURSI.pdf] (20.04.2016).

${ }^{8}$ Usp. Brnčić, nav. dj., 744-745.

${ }_{9}$ Usp. isto, 732.

${ }^{10}$ Usp. isto.
} 


\section{Autobiografski diskurs Vesne Parun i metafore sebstva}

U istraživanjima ruske teoretičarke Lidije Ginzburg o problemima odnosa između ličnosti u životu i ličnosti u književnosti, prema M. Medarić nailazi se na plauzibilno argumentiranje postavke o tome da je metoda kojom se čovjek služi u procesu izgradnje vlastite psihičke strukture zapravo metoda analogna umjetničkoj, ${ }^{11}$ što je donekle usporedivo s Ricœurovom tezom o udjelu narativne konfiguracije u konstruiranju sebstva. Renata Jambrešić konstatira da se tradicionalno proučavanje hrvatske književnosti većinom odricalo najvećeg dijela autobiografske produkcije »u ime ozbiljnosti intencije 'velikih muževa' za vjerodostojnim, cjelovitim i univerzalno prihvatljivim samoopisom $~^{12}$ pri čemu su autobiografije najširi prostor $»$ proizvodnje subjektivnosti ${ }^{13}{ }^{13}$ Autobiografski tekstovi gotovo uvijek su se naručivali od književnika i društveno priznatih osoba, a oni bi potom diskurzivno oblikovali osobni model za javnost kojim se žele predstaviti te istodobno i ovjeriti unutar socijalne, političke i kulturne recepcije. ${ }^{14}$ Ukoliko su, prema S. Grakalić-Plenković, rođenje, školovanje, služba, trenutno zaposlenje i osvrt na objavljena i napisana djela tematski krugovi koje možemo nazvati nezaobilaznima u poimanju javne autobiografije, dok su razlike među piscima primjetne na razini kompozicije, ${ }^{15}$ onda metafore sebstva s pravom možemo smatrati ključnim elementom u književničkoj autobiografiji Vesne Parun jer se po njima autorica posve odvojila od tradicije ovoga žanra $u$ hrvatskoj književnosti ${ }^{16}$ približavajući ga suvremenom poimanju autobiografije

${ }^{11}$ Usp. Magdalena MEDARIĆ, Autobiografija/Autobiografizam, Republika, 49 (1993) 7-8, 57.

${ }^{12}$ Renata JAMBREŠIĆ, Proizvodnja subjektivnosti. Andrea Zlatar: Autobiografija u Hrvatskoj. Nacrt povijesti žanra i tipologija narativnih oblika, Kolo, 9 (1999) 3, 233.

${ }^{13}$ Isto.

${ }^{14}$ Usp. Helena SABLIĆ-TOMIĆ, Intimno i javno. Suvremena hrvatska autobiografska proza, Zagreb, Naklada Ljevak, 2002, 16.

${ }^{15}$ Usp. Sanja GRAKALIĆ-PLENKOVIĆ, Autobiografije hrvatskih književnika u »Almanahu srpskih i hrvatskih pjesnika i pripovjedača 1910«, u: Diana STOLAC (ur.), Riječki filološki dani, 9. zbornik radova, Rijeka, Filozofski fakultet, 2014, 105-106; https://bib.irb.hr/ datoteka/736476.11-RFD9_Grakalic-Plenkovic_Sanja.pdf (25.04.2016).

${ }^{16} \mathrm{U}$ radu o autobiografijama hrvatskih književnika moderne S. Grakalić-Plenković analizirat će prvu hrvatsku zbirku naručenih autobiografija pisaca Almanah srpskih $i$ hrvatskih pjesnika $i$ pripovjedača 1910., tiskanu u redakciji Milana Curčina i Branimira Livadića, koja je potaknula povećan interes za ovaj žanr (Grakalić-Plenković, nav. dj., 103). Usporedba sa zaključcima koje ova autorica ističe o autobiografijama hrvatskih pisaca u Almanahu iz 1910. pokazuje u kolikoj se mjeri autobiografski diskurs Vesne Parun razlikuje od postupaka tradicionalne književničke autobiografije. Naime, ovi su autori »pokazali naklonost promatranju vlastitoga rada objektivnim očima sakupljača 'pouzdanih' biobibliografskih činjenica, a publika je, uvijek sklonija pogledu iznutra, izgubila dojam potpune autentičnosti. Almanah tako donosi autobiografije bez velikih stilskih i umjetničkih ambicija, kojima su, u odsustvu nadahnuća, pomalo pretenciozno, autori sami sebi napisali popis važnijih godina, djela i nagrada. Svoju svijest o važnosti recepcije almanahovci će potvrditi nabrajanjem pseudonima, te svojevrsnim moralnim ili didaktičkim porukama kojima će se, kroz prizmu savjetovanja za budućnost, osvrnuti na vlastite odluke i životne puteve koje su birali. Društvena i književna odgovornost autobiografa promatranog korpusa očituje se nadalje na književnom, društvenom, kulturnom i političkom 
kao ontološkog žanra. ${ }^{17}$

Za većinu je, prema Ricœuru, identitet osobe/zajednice sastavljen od vrijednosnih identifikacija s normama, idealima, uzorima, herojima, u kojima se osoba/zajednica prepoznaje. ${ }^{18} \mathrm{U}$ tom smislu, $\mathrm{u}$ autobiografskom diskursu Vesne Parun dolazi do izrazitog odmaka i približavanja definiciji sebstva

»kao svijesti refleksivnog subjekta u permanentnom, dinamičkom, dijalektički otvorenom i nikad do kraja dovršenom samotraženju, samotumačenju i samorazumijevanju koje krči svoj put kroz sumnju i povjerenje. Dijalektika sumnje i povjerenja odigrava se unutar subjekta koji u vremenu ostaje isti pojedinac, ali čiju samostojnost tvore brojne promjene u vremenu, tj. između nepromjenjive trajnosti relativne postojanosti sebstva i neprestane njegove promjenjivosti u vremenu. Drugim riječima: samorazumijevanje se događa u dijalektici između istosti i brojnih njegovih unutarnjih drugosti. ${ }^{19}$

Prva autobiografija Vesne Parun objavljena je u zagrebačkome tjedniku Globus 1958. godine pod naslovom »Autobiografija u deset rečenica«. Autobiografskog je značenja i njezina knjiga Krv svjedoka (1988.), a u pogovoru knjizi Začarana čarobnica (1993.) autorica je objavila autobiografski tekst u trećem licu »Vesna Parun o Vesni Parun $«{ }^{20}$ Prema M. Velčić, autobiografski diskurs karakterizira osobina da se može uklopiti u sve govorne žanrove i da se može očitovati u svakoj vrsti teksta. ${ }^{21}$ Magdalena Medarić autobiografizmom naziva stilski markiran književni postupak koji je refleks žanra autobiografije, a javlja se u tekstovima koji sami po sebi nisu mišljeni ni recipirani kao autobiografije. ${ }^{22}$ Znanstvenica ne propušta spomenuti i autobiografske tekstove u kojima autor uvodi sebe u liku pisca pa tematizira vlastiti književni postupak, raspravlja o umjetnosti općenito. Za nju će biti zanimljivi takvi slučajevi (a češći su kako idemo prema postavangardi ili postmodernizmu) u kojima je autor konkretizirao sebe, umjetnika, i kao empirijsku osobu ili konkretnog umjetnika u vremenu i prostoru. Kod umjetnika je teško razlučiti te dvije sfere, javnu i intimnu, jer se one preklapaju. ${ }^{23}$

Korpus istraživanja u ovome radu stoga će uključiti i ranije objavljene tekstove Vesne Parun koji isprva nisu nužno nastajali s intencijom pisanja autobio-

planu, što dokazuju jasna određenja prema aktualnim društvenim događanjima koja iskazuju « (Grakalić-Plenković, nav. dj., 107).

${ }^{17}$ Autobiografija je ontološki žanr jer svojom temom, autorovim vlastitim životom, problematizira osobnu zbilju koja se pojavljuje u ambivalentnom obliku: kao prava, realna zbilja i kao fikcija živoga autorskoga lika (Dubravka ORAIĆ TOLIĆ, Paradigme 20. stoljeća. Avangarda i postmoderna,Zagreb, Zavod za znanost o književnosti Filozofskoga fakulteta Sveučilišta u Zagrebu, 1996, 113).

${ }^{18}$ Usp. Brnčić, nav. dj., 735.

${ }^{19}$ Isto, 738.

${ }^{20}$ Usp. Vinko BREŠIĆ, Autobiografije hrvatskih pisaca, Zagreb, AGM, 1997, 1260.

${ }^{21}$ Usp. Mirna VELČIĆ, Otisak priče. Intertekstualno proučavanje autobiografije, Zagreb, August Cesarec, 1991, 30.

${ }^{22}$ Usp. Medarić, nav. dj., 46.

${ }^{23}$ Usp. isto, 54-55. 
grafije, ali se mogu karakterizirati kao autobiografska proza (eseje: Pod muškim kišobranom, 1986., Poljubac života, 1993., Do zalaska sunca hodajući za kamilicom, 1958.), kao i onoga koji to dominantno jest (Noć za pakost. Moj život u 40 vreća, autobiografija pisana od 1999. do 2001.), a zajedno su ušli u tako naslovljenu zbirku, objavljenu 2001. godine. ${ }^{24}$ Po potrebi ćemo se dotaknuti i autobiografskih komentara vlastitih pjesama koje je autorica sabrala i objavila u knjizi Ja koja imam nevinije ruke (2009.). ${ }^{25}$ Funkcija postupka autobiografizma ili autobiografičnosti izvan žanrovski omeđenog područja dijeli se na: a) samoizražavanje, odnosno propitivanje subjekta teksta kao autora, b) problematiziranje same književne strukture kao teksta, djela, predmeta komunikacije, c) ludističku funkciju, poigravajući odnos autora s čitateljem (pojava autora kao empirijske osobe u romanu, ali u funkciji svojevrsnog potpisa). ${ }^{26}$

Prema Ricœuru pripovjedni glasovi naše životne priče imaginativne su varijacije našega ega posredstvom kojih nastojimo doći do samorazumijevanja. Narativni identitet je odnos među pripovjednim glasovima kojim nastojimo doseći »apsolutni identitet «. ${ }^{27}$ Moj narativni identitet nije moj identitet u priči koju o sebi mogu ispričati, nego u mojoj narativnoj sposobnosti da to činim. Proces konfiguracije nije dovršen u tekstu, nego se dovršava u čitatelju. Pod karakterom Ricœur razumije skup razlikovnih oznaka koje dopuštaju da se reidentificira ljudska jedinka kao jednaka samoj sebi. Putem deskriptivnih oznaka karakter označava skup trajnih stanja (stečenih navika i identifikacija) po kojima prepoznajemo neku osobu. ${ }^{28}$

Autobiografski diskurs Vesne Parun oblikuje se

»u kontekstu hrvatske književnosti kada dolazi do zgušnjavanja personalnosti, diskurzivnog oblikovanja te personalnosti kao i do razumijevanja individualizacije kao procesa koji je nužno posljedica socijalnog okruženja i samosvijesti u njemu«. ${ }^{29}$

Taj se proces intenzivirao u suvremenoj hrvatskoj književnosti nakon 1968. godine, kada se dekonstrukcija i demontaža totalitarnoga sustava ogledaju

\footnotetext{
${ }^{24}$ I. Bošković će u prikazu zbirke Noć za pakost. Moj život u 40 vreća navesti da je »uklopiva u aktualni autobiografski književni trend - ne samo brojem nego kao njegov bitni književni dobitak - pisana je i prepisivana, kako veli, nekoliko puta rukom ('bolesna, umorna, kašljući u krevetu'), a potaknuta je krajem 1988. nakon dvaju pohoda Dalmaciji; zapravo nastajala je cijeloga života, koji je u njezin prilagodljivi žanrovski okvir 'upisivao' bolne i mučne sadržaje« [Ivan BOŠKOVIĆ, Gospa krivovirna pravca (Vesna Parun: Noć za pakost. Moj život u 40 vreća, Zagreb, Matica hrvatska, 2001), Slobodna Dalmacija, 11. rujna 2001.].

${ }^{25}$ Ta je zbirka (Ja koja imam nevinije ruke, 2009.) na poseban način važna za istraživanje književnosti kao metafore sebstva u autobiografskom diskursu V. Parun, budući da njezini komentari u podtekstualnim zapisima nose izrazito autobiografska obilježja. Čitava se zbirka može razmatrati kao autobiografija u prozi i stihu (makar se autobiografski žanr tradicionalno definira isključivo prozom, što otvara nove mogućnosti njegova istraživanja).

${ }^{26}$ Usp. Medarić, nav. dj., 59-60.

${ }^{27}$ Usp. Brnčić, nav. dj., 734.

${ }^{28}$ Usp. isto, 734, 735.

${ }^{29}$ Sablić-Tomić, nav. dj., 9.
} 
upravo u žanru osobnih priča. ${ }^{30}$ Za hrvatske spisateljice 80 -ih godina 20. st. koje su također stvarale autobiografski diskurs (I. Vrkljan, S. Drakulić, D. Ugrešić i S. Škrinjarić), Andrea Zlatar će navesti da ih karakterizira vješto i samosvjesno poigravanje $\mathrm{s}$ autobiografskim ugovorom ${ }^{31}$ te narativnim strategijama koje pridonose autobiografskom učinku realnog i učinku osobnog. Odlikuje ih tipološka nedeterminiranost, svjesno podrivanje monolitnosti romaneskne prakse, evokativno i monološko razvijanje priče te točka gledišta »izvanjštene osobnosti «. ${ }^{32}$

Autobiografski diskurs Vesne Parun manjim dijelom slijedi model memoara, koji H. Sablić-Tomić definira pozicijom subjekta, obično javne osobe koja sudjeluje u opisanim zbivanjima, ${ }^{33}$ međutim ono po čemu i ovdje vidimo značajan odmak spisateljice od toga modela jest činjenica da ona ne nastoji zadržati poziciju objektivnog promatrača (što ulazi u definiciju memoara ${ }^{34}$ ). Dapače, na više mjesta autorica ističe kako joj je čin dokumentarnog samoizricanja bio težak. [»A meni je bilo teško uzeti papir, napisati datum i naškrabati dvije do tri dokumentarne, prozne rečenice. (...) Umjesto da bilježim događaje i likove, pomamno sam rasterećivala dušu ucrtavajući u bilježnicu utvare.«35] Ipak, memoarskom ostaje namjera autorice da prenese neke događaje i opise ljudi u određenom društvenopolitičkom i kulturnom trenutku, pri čemu autoričino intimno (ukoliko slijedimo podjelu $\mathrm{H}$. Sablić-Tomić) nipošto nije privatno (kako je uobičajeno u memoarima, ${ }^{36}$ nego, i zbog same činjenice da je riječ o najvećoj hrvatskoj pjesnikinji 20. stoljeća, njezino intimno jest javno. ${ }^{37}$ To

\footnotetext{
${ }^{30}$ Usp. isto, 12.

${ }^{31}$ Pojam Philippea Lejaunea koji je autobiografiju definirao putem odnosa između čitatelja i autora i taj odnos nazvao autobiografskim ugovorom. Osobno ime autora, pripovjedača i protagonista obećava autentičnost svega zapisanoga, ali taj se ugovor može ponuditi čitatelju (drugom partneru ugovora) na različite načine. Uporaba prvog lica jednine nije dovoljna jer se ne razlikuje od 1. lica jednine kod fikcionalnog pripovjedača, no sljedeće indicije smatra dovoljnima: a) odabir naslova, b) intencija izrečena na početku teksta i c) spominjanje vlastitog imena u tekstu. Kasnije se posumnjalo u posvemašnju relevantnost ovih indicija. I sam Lejeune, primjerice, 1977. napisao je studiju Autobiografija u trećem licu [usp. Philippe LEJEUNE, Autobiografski sporazum. Autobiografija i povijest književnosti, u: Cvjetko MILANJA (prir.), Autor, pripovjedač, lik, Osijek, Svjetla grada, Sveučilište Josipa Jurja Strossmayera, 2000, 201270 i Eigler, nav. dj.]

${ }^{32}$ Vidi: Andrea ZLATAR, Autobiografija u Hrvatskoj. Nacrt povijesti žanra i tipologija narativnih oblika, Zagreb, Matica hrvatska, 1998, 110-118 i 119.

${ }^{33}$ Usp. Sablić-Tomić, nav. dj., 23.

${ }^{34}$ Usp. isto, 23.

${ }^{35}$ Vesna PARUN, Noć za pakost. Moj život u 40 vreća, Zagreb, Matica hrvatska, 2001, 43.

${ }^{36}$ Usp. Sablić-Tomić, nav. dj., 23.

${ }^{37}$ Usporedbe radi, Nenad Ivić u raspravi o autobiografskom diskursu u Kolu 1999. navodi da u srednjovjekovlju i antici ne postoji individualitet koji bi se mogao brisati da bi postajao javan, nego je figura iskazivanja osobnosti (služeći se pojmom A. Zlatar) upravo u javnosti, u preuzimanju javnoga (u Grčkoj 6. stoljeća to je slava junaka, u Rimu se Rimljanin individualizira slikama predaka, itd.) Osim toga, vidljivo je i ogledanje u literaturi, npr. kod Augustina gdje ovaj postaje Ciceronov Hortenzije [vidi: Signali autobiografskoga diskursa. Rasprava, Kolo, 9 (1999) 3, 241-260, 244].
} 
je tzv. književnička autobiografija kod koje se općenitom karakteru nacrta u svakoj autobiografiji pridružuje i shvaćanje samoga sebe kao autora te vlastiti komentar o ranije nastalim djelima. Sigurd Paul Scheichl taj oblik književničke autobiografije označava kao »metaknjiževnu funkciju«. ${ }^{38}$ Prema Paulu de Manu (kojega ističe F. Eigler prikazujući dekonstruktivističku poziciju razmatranja autobiografije i narušavanja idealističkog referencijalnog odnosa autor-djelo), kada se ideja o autonomnom pojedincu koji ima nadzor nad tekstovima što ih je sastavio, odbaci kao iluzija i ako se umjesto toga polazi od pretpostavke da se subjekt u činu pisanja oslobađa, rješava i odriče teksta, tj. na vlastiti tekst gleda kao na nešto tuđe, tada razlikovanje fikcionalnih i autobiografskih tekstova postaje u krajnjoj liniji nevažno:

»Autobiografija onda nije žanr ili modus, nego oblik (figure) čitanja ili razumijevanja koji se u stanovitoj mjeri pojavljuje u svim tekstovima.« ${ }^{39}$

Zato nas ne treba čuditi što se neke od metafora sebstva koje ćemo u ovom radu obraditi kao elemente autobiografskog diskursa, mogu pronaći i u drugim književnim tekstovima Vesne Parun, primjerice u poeziji. Prema tipu autobiografije, Vesnina bi bila asocijativna, koja podrazumijeva akronološko prisjećajuće pripovijedanje, fragmentarno samoprikazivanje, kojemu je povod osoba, predmet ili događaj značajan za autorov život. ${ }^{40}$ Ta osoba, događaj ili predmet jest »drugost« koja postaje konstitutivnom sastavnicom spisateljičina sebstva odnosno iskazanoga narativnog identiteta. U tom smislu kod Vesne Parun ističu se: muški kišobran, zemljovid, vreće te vlastiti književni tekstovi.

\section{a) Književnost/poezija kao metafora sebstva}

Autobiografski tekstovi V. Parun su autometatekstualni u smislu da nose sposobnost referiranja na neki svoj aspekt, dio komunikacijskog lanca, neku svoju strategiju ili nešto što se tiče njegova vlastita izraza ili sadržaja. Istražujući načine i funkciju metaforiziranja vlastitih, ranije objavljenih književnih tekstova u književničkoj autobiografiji, izravno ispitujemo spomenutu Olneyevu tezu o eksperimentatoru (piscu autobiografije) koji promatra cjelinu eksperimentator-eksperiment (kontekstualiziranje i nadopisivanje vlastitih književnih tekstova u tekstu koji upravo nastaje), ali i samoga sebe u stanju promatranja (propitivanje vlastitog javnog i osobnog identiteta). U istraživanju metafora kojima Vesna Parun izražava sebstvo (u smislu spomenute Ricœurove polisemije drugosti), ne mogu se zaobići smjerokazi kojima sugerira svoja iskustva vlastite

\footnotetext{
${ }^{38}$ Prema Eigler, nav. dj.

${ }^{39}$ Paul de MAN, Autobiography As De-Facement, 1979, u: The Rhetoric of Romanticism, Columbia Univ. Press, Yale, 1984, 70, cit. u: Eigler, nav. dj.

${ }^{40}$ Usp. podjelu H. Sablić-Tomić, nav. dj., 24. Ista će znanstvenica u Noći za pakost primijetiti kronologiju, ali onu koja je uspostavljena na razini fikcijskoga vremena (usp. str. 191).
} 
svijesti, tijela, drugih osoba, društvenih konvencija i ideologije, pa sve do odnosa prema vlastitoj poeziji.

»Pretpostavke na kojima sam gradila svoj intimitet bile su, dakle, posve reakcionarne, i nije mi preostalo nego da zauvijek posumnjam u tezu o sreći utemeljenoj na bilo kakvoj poslušnosti bilo kome - pa čak i vlastitom u igru pokera neupućenom srcu. $\ll^{41}$

»Moja budućnost. Što je to uopće? Studij? Zavičaj? Brak? Sve je iščašeno. I Kant i Marx nakon mog tifusnog stresa - u staro željezo! Nastupit će dugotrajna i sudbonosna alergija na čitanje, logofobija. (...) Ali žrtva je prinijeta: aždaja Podobnost progutala je dobačenu mu u ždrijelo djevicu. I sretna preživa...«42 »Da, tu je, unatoč svemu, i poezija... Ta prva i posljednja ljubav mog života neće li i ona biti, po obrascu svuda prisutnih himera, skrovište izdaje? « ${ }^{43}$

Književnost je za Vesnu Parun bila »duhovni otpor zbilji, obmani, kaosu« i »egzistencijalno anti-vrijeme«, što su sintagme koje je koristila u referatu na Mariborskoj skupštini Saveza jugoslavenskih pisaca 1986. godine. ${ }^{44} \mathrm{Za} » r i j e c ̌ \ll$

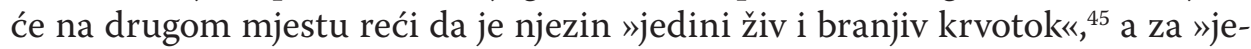
zik« da je njezina »duboka i strasna intima. I najveća moja baštinska identitetska obaveza. «6 Ipak, sam autobiografski diskurs za nju je javni čin, prispodobiv spomenutoj dekonstruktivističkoj poziciji;

»kojim se autor oprašta hrabro od svojega djela, a poistovjećuje s magnetskom spiralnom žicom, s otvorenom krivuljom sudbine, s heksagramom svoje posljednje, iscrpljujuće življenske preobrazbe «. ${ }^{47}$

Zbiljski život i poezija na suprotnim su stranama:

»Ali u tome i jest suština nesporazuma. U nepodudarnosti modela i slike. U hladnoći estetske istine, koja, budući u obrnutom razmjeru s emocionalnom, ostaje kao jedini svjedok kojemu se vjeruje, jedini autentičan dokument. «8

premda ne postoji stvarna granica između poezije i sebe:

»(...) budući da sve bez prestanka teče, pa tako otječe od tebe i tvoja poezija, što ti preostaje nego da sjedeći na obali rijeke grabiš šakama tu bivšu rijeku i promatraš je. Tu rijeku, tu bivšu poeziju, taj pijesak. To sutrašnje tvoje novo JA, preporođeno i tebi još nepoznato. Tu granicu između ovdje i tamo, sada i sutra, ti i netko drugi. $\ll^{49}$

\footnotetext{
${ }^{41}$ Parun, Noć za pakost..., 22.

${ }^{42}$ Isto, 26.

${ }^{43}$ Isto.

${ }^{44}$ Usp. Vesna PARUN, Pod muškim kišobranom, Zagreb, Delo, 1987, 151-158.

${ }^{45}$ Vesna PARUN, Ja koja imam nevinije ruke. Asinkroni odabir, Zagreb - Sarajevo, Zoro, 2009, 21.

${ }^{46}$ Isto, 28

${ }^{47}$ Parun, Noć za pakost..., 41.

${ }^{48}$ Isto, 39.

${ }^{49}$ Isto, 42 .
} 
Već u prvom, uvodnom tekstu zbirke Noć za pakost, pod naslovom Poljubac života (1993.) autorica nagovješćuje autometatekstualni pristup u smislu komentiranja vlastitih objavljenih književnih tekstova, u prvom redu poetskih, koji su postali kanonska djela hrvatske književnosti, ili uporabom njihovih elemenata, svojevrsnim nadopisivanjem istih u tvorbi novoga teksta. Na dokumentarnoj razini uvodni esej donosi autoričino iskustvo iz srpnja i kolovoza 1947., kada je na radnim akcijama u Bosanskom Brodu oboljela od tifusa. Navodimo primjere metaforičkog nadopisivanja naslovne sintagme zbirke Vidrama vjerna, 1957., ili aludiranja na elemente pjesme Za sve su kriva djetinjstva naša:

»Da mi je ostati ovako pod vrbom, s glavom u vodi, čekati noć i vidru da me povede u svoj čarobni dvorac od sna i poezije. U dvorac za koji sam tada još vjerovala da je, ako ne stvaran, a ono bar iluzijom moguć. Jesam li odista svim vidrama naše prevarene i obezdomljene mladosti ostala bezdomno vjerna? «50

»Nije mi žao mene. Žao mi je svih u zamku uhvaćenih djetinjstva, na koja pada sve gušća i tamnija sjena autoritativnog Nepostojećeg. «151

Nailazimo i na opise vanjskih okolnosti u kojima su nastajali neki od Vesninih stihova, konkretno onih koji su ušli u osporavanu zbirku Pjesme (1948.), a povezani su s iskustvom boravka u bolnici:

»Upala srčanog mišića - zapisali su na tablicu i objesili je. Da sam je mogla privući k sebi, naškrabala bih na njoj jednu strofu koju se grdno umorih pamtiti, a bez nje nikako ne mogu. Kladila bih se da je to bila baš ova:
A Mjesec, djedo sa srebrnom gušom
brojač vjekova s puškom o ramenu
uokolo hoda planinskom tmušom
u bajke skriva dušu kamenu...

To mi se poput neželjena uljeza, motalo po glavi još u baraci, na strunjači, a neke druge pokupih s plićaka Bosne onda dok lupah čelom i potiljkom o njegov hladan šljunčan mozaik. «2

Zanimljivo je da će na drugom mjestu autorica ovu »mjesečevu gušu« izravno povezati s vlastitom sudbinom i bolešću koja joj se razvila u kasnijim razdobljima života, u tekstu koji je nastao 16 godina kasnije u obliku komentara ispod pjesme Maglaj (u kojoj se nalazi gore spomenuta strofa): »I ja ju imam. Neka se zna otkud mi duša. $\aleph^{53}$ Opisane sekvence boravka u bolnici, gladi i bolova, ali i poezije koja je u ranijem citatu predstavljena kao svojevoljno, živo biće koje se nameće svijesti pjesnikinje, prožimaju se autoričinim komentarima o onodobnoj ideološkoj kritici zbirke Zore $i$ vihori:

\footnotetext{
${ }^{50}$ Isto, 14.

${ }^{51}$ Isto, 26.

${ }^{52}$ Isto, 17.

${ }^{53}$ Parun, Ja koja imam nevinije ruke..., 2009, 39.
} 
»A treći - uspravan i gord, samom kipu božice Pravde nalik, dogmagoj - zveknu nada mnom pozlaćenom vagom Moći i, odozgo nadolje, suho će ne trepnuvši okom:

- Znaš, napisao sam o tvojim stihovima kritiku, izašla je (ili 'izaći će', ne sjećam se više) u 'Republici'. Ne sumnjam da sam ocijenio pravilno, i ne bi se moglo reći prestrogo, vrline i mane tvoje zbirke. Ovo vrijeme ne dopušta pogreške. Revolucija traje, obnova zemlje zahtijeva visoku klasnu svijest i od nas umjetnika...

Trebalo je zapravo da pristojno odsalutiram odozdo:

- Razumijem, druže umjetniče Marine Franičeviću! Pokorno izjavljujem, imat ću to na umu!... « ${ }^{54}$

Prisutni su i autoričini komentari vlastitih stilogenih postupaka koji u tekstu postaju poticaj za aforističko osvrtanje na društvenu stvarnost:

»U mom je slučaju zarez na pravom mjestu. A gdje će politika stavljati svoje zareze, za to su antička proroštva skroz nemoćna.... ${ }^{55}$

Jedna od rečenica koja čitatelja uvodi u važnost percipiranja autoričine poezije u cjelini njezina samoprikazivanja, kaže:

»A mene nema. Moja unutrašnja radionica riječi kako je pusta. Nisam li htjela dovršiti zadnju strofu jedne stotinu milja od mene udaljene pjesme? ${ }^{56}$

Autorica stavlja težnju za iskazom svoga života ispred same poezije (kojoj negira tu mogućnost), svjesna paradoksalnosti toga odabira jer poezija jest središnji dio nje same i odnosa prema drugome, u sebi i izvan sebe:

»Meni je, međutim, upravo taj moj vrtoglavo-sunovratno prijeđeni put značajniji od bilo čega na svijetu, te da ga rasvijetlim i prikažem onakvim kakav je on bio i kakav jest, žrtvovala bih sve što ikad izrazim jezikom stiha, lepršavom simbolikom metafore. U toj mojoj tvrdnji sadržan je, očito, apsurd - jer kome bi bilo uopće stalo do pjesnikove intimne sudbe, ma kakva bila, do golih podataka, da se ona već nije poput clowna na vašaru budzašto izrazdavala poezijom. « ${ }^{57}$

Poezija je suprotstavljena stvarnosti pjesnikinjina života, dakle i ona predstavlja »drugost« bez koje se ne može definirati sebstvo:

»Shvatio si da je poezija bila tek jedna od supstanci - najsublimnija, doduše tvog zemaljskog žića, ali nikako ne život sav, i da je on divlja neukroćena ptica što je samo proprhnula krišom kroz neveselu krletku poezije i izletjela iz nje ponovno van, na slobodu, u prelijepu divljinu zbilje, u vakuum gdje nema osluškivanja asonanci i sladostrašća metrike i ritma. $\aleph^{58}$

\footnotetext{
${ }^{54}$ Parun, Noć za pakost..., 21.

${ }^{55}$ Isto, 24.

${ }^{56}$ Isto, 10.

${ }^{57}$ Isto, 38.

${ }^{58}$ Isto, 39.
} 
Pjesma Ti koja imaš nevinije ruke na više se mjesta donosi kao metafora sebstva autorice. Ta, možda najčuvenija ljubavna pjesma hrvatske književnosti 20. stoljeća, u pjesnikinjinom autobiografskom tekstu prikazuje se kao predmet poruge bližnjih, ali i kao mjesto ironičnog samoosporavanja, jer je skrila u sebi istinu o autoričinu pokušaju samoubojstva zbog osobe kojoj je posvećena:

»Pročitali su u 'Republici' (...) Ti koja imaš nevinije ruke i rugali se: kako uljepšava, gle, kako zauzima pozu! A gdje su joj u toj pjesmi bolnička nosila, zavijanje sirene usred noći, raščupana kosa, glava gažena cipelama onih za čiji se miran san u toj lažipjesmi usrdno moli! Gdje gumena cijev za stomak, potvrde socijalnog osiguranja, gomile knjiga po tuđim drvarnicama, potucanje od nemila do nedraga, košmar, spleen... $\ll^{59}$

Književnost je u diskursu Vesne Parun mjestimice čak i antropomorfizirana:

"Stih je okrutan, njega se ne tiče jesi li mrtav ili živ, njemu je potrebna nečija ruka da ga zapiše, nečije stvaralačko biće da ga - maljem jezika - sačini ni iz čeg. Stihovi su monstrum koji se koristi energijom tvoje žive patnje, da bi održao u vještačkom životu svoj savršeno složen mehanizam, pomoću kojega trijumfalno i bestidno oponaša smrtni čovjekov krik. «60

»Nisam, rekoh, nikada vodila dnevnik. Ali on se, nevidljiv na papiru, pisao godinama negdje unutra u meni. Pisao se sam, u sablasnoj šutnji, i ne pitajući me za pristanak. Pisao se bez riječi, bez rečenica, bez gramatičkih oblika, pravopisnih zakučica. Znala sam da se to događa. Znala sam da se on piše, taj moj dnevnik $(\ldots) \ll^{61}$

»Ali je pjesma, one noći napisana, nadživjela na papiru sve što je odonda za mene pretvoreno u pepeo. $\varkappa^{62}$

\section{b) Muški kišobran}

Helena Sablić-Tomić uočava snažno individualiziranu strategiju mišljenja spisateljice kroz potrebu za propitivanjem ženskoga identiteta u tekstu i izvanknjiževnoj zbilji, ${ }^{63}$ što se u autobiografskom diskursu Vesne Parun možda najjače iščitava upravo metaforom muškog kišobrana. Njegovo je značenje isprva razrađeno u esejističkom tekstu Pod muškim kišobranom. Muški je kišobran $\mathrm{u}$ izravnoj metaforičkoj vezi s njezinom poezijom jer je knjiga (naslovljena »muškim kišobranom « iz 1987. godine, u kojoj je istoimeni esej) nastala, prema riječima autorice, da bi pokazala "poeziji njena dvojnika«, ${ }^{64}$ te kao »osvrtaj i

\footnotetext{
${ }^{59}$ Isto, 40.

${ }^{60}$ Isto, 39-40.

${ }^{61}$ Isto, 43-44.

${ }^{62}$ Isto, 45.

${ }^{63}$ Sablić-Tomić, nav. dj.,190.

${ }^{64}$ Parun, Noć za pakost..., 49.
} 
traženje korijena sebe od danas u onome što je rascvjetavalo krošnju stablu od jučer«) ${ }^{65}$ Stoga muški kišobran za autoricu nije samo

»utemeljitelj ove naše blagoslovljene i uklete, sanjarske, tehnokratske, kućne, morbidne i još uvijek robovlastičke civilizacije. Civilizacije muške, protekcionističke, ratničke, biznismenske. Razumom sve arogantnije. Nerazumljem sve zasićenije. I, na svu sreću, već dobrano na izdisaju.« ${ }^{66}$

On je simbol očinske moći, i to konkretnog, inzularnog muškarca s kompleksom manje vrijednosti, kako definira svoga oca koji daje snažan pečat njezinom identitetu, ${ }^{67}$ pa je kao ta, inicijalna »drugost «, uključen u njezino sebstvo.

»Kišobran otočanina: njegov inzularni kompleks manje vrijednosti (...) Rekvizit bez kojega su nezamislivi autoritet, zakon i red. Pater familias bez kišobrana to je kao kuća bez krova. Otoci Brač, Hvar, Prvić, Šolta, Vis... Privatni posjed, obitelj, škola, država, crkva, ured. Muški kišobran. « ${ }^{68}$

»U hodniku, u mraku, spoticali smo se o nj neizbježno i vriskali pri tom od straha, a on se vršcima žica kao bodljikama hvatao za nas, kotrljao se za nama mokar i sulud, nevidljiv, čineći od nas još zarana neuropate, somnabule, bezbožnike i buduće anarhiste.« ${ }^{69}$

Muški kišobran zbog svega toga postaje svjesno izabranim znakom njezine različitosti:

»Nosit ću sa sobom, umjesto batine, muški kišobran i rastvarat ću ga kad god se crne oblačine obzorjem nadviju. I jer sam žena, bit ću zbog toga rekvizita svjesna sam - smatrana ne samo ekscentričnom i luckastom, nego će se i moj trnovit ženski, da, upravo beznadno ženski povijesni put priviđati kao hrpa nereda i proturječja. Kao živa potvrda znamenitoj tezi da čovjek kao osoba, dodala bih - nije ono što o sebi, da parafraziram dalje, poezijom kazuje. i $^{70}$

I sama poezija nastaje pod kišobranom pa se njegov metaforički potencijal može donekle usporediti s metaforom »vlastite sobe« koja u tradiciji tzv. ženskog pisma označava pravo žene na izraz, na stvaranje teksta, vlastitu književnu kreaciju i upisivanje ženskog iskustva u književni kanon. Muški, očev kišobran otvorila je nad papirom ne bi li uspjela napisati autobiografiju, a on se, gotovo paradoksalno, poistovjetio s njezinom lirikom dekonstruirajući zadane društvene i rodne odnose koji su, suprotnom metaforom »šarmantnijeg od

\footnotetext{
${ }^{65}$ Isto.

${ }^{66}$ Isto, 35.

${ }^{67} \mathrm{U}$ ovaj kontekst autorica stavlja dokumentarne podatke o trenutku svoga rođenja binarno polarizirajući sliku i funkciju svojih roditelja. »Otac, neraspoložen da se po oštru kamenju, u mraku uzvere čak do u selo po babicu Voku, naredio je majci neka se strpi - za miloga Boga - bar do svanuća. Majka, strpljiva i predana kakva je bila, zacijelo bi mu bila ispunila i taj nemogući supružanski prohtjev. Ali ja sam bila bezobzirna. I to je bio moj prvi nijemi sukob s onim koji mi je još u majčinoj utrobi namijenio ime SUVIŠNA« (isto, 37).

${ }^{68}$ Isto, 37.

${ }^{69}$ Isto, 35.

${ }^{70}$ Isto, 38.
} 
ovog i delikatnijeg 'ženskog kišobrana' «, ${ }^{71}$ trebali biti upisani u temelj njezina osobnoga identiteta:

»Zaključala sam se od jada i ostala tako mjesecima. Obnoć bi izašla poput sove iz duplje, pojela što je majka ostavila u zdjelici pred vratima i nastavila pisati. Ne Nalik na život, ne autobiografiju. To je bilo, jaoh, neostvarivo. Pisala sam tada Crnu maslinu, pod velikim crnim okrezubljenim muškim kišobranom. « ${ }^{72}$ »Kako se osjeća u svojim već poodmaklo zrelim godinama žena koji bi kao žena bila doista po očevu proroštvu, SUVIŠNA - da nije bilo tog muškog, moglo bi se reći, staromodnog kišobrana lirike, kojim je branila svoj identitet od najezde dvonožnih sisavaca što uzurpatorstvom tek postaju ljudi (...) Dok steknu pravo na svoj vlastiti široki i duboki crni štovanja vrijedan skupocjeni muški kišobran, pod koji će smjestiti udobno i sebe i svoj svjetonazor, i svoju širu i užu obitelj, a s vremenom - posreći li se - i svoje institucije. ${ }^{73}$

U eseju Pod muškim kišobranom vidimo kako diskurs koji je građen nadopisivanjem ranije objavljenih poetskih tekstova autorice mjestimice postaje vrlo angažiran i kritičan, i to baš kada je u pitanju odnos između javne ličnosti pjesnikinje, koja se društveno konstruirala recepcijom njezine poezije, i njezine »zbiljske«, »privatne« ličnosti (sukobljenost narativnog i osobnog identiteta):

»Zašto u pjesničkom buncanju smijem uzviknuti: Bila sam dječak, a ne smijem se pozvati na taj svoj ekspresionistički stih u sudnici, te ako mi ga spomene netko ondje, moram se čuvati da mi ne dovedu - kao što se jednom već dogodilo - u ime zakona ništa manje no tri sudska vještaka, psihijatra, dakako - da bi utvrdili (...) građansku dijalizu mog duha i njegovu socijalnu upotrebljivost. « ${ }^{74}$

\section{c) Zemljovid}

Metaforom zemljovida otvara se sljedeći tekst Noć za pakost koji uvodnim sekvencama slijedi ili pokušava slijediti klasičan autobiografski diskurs prikazom autoričina djetinjstva. Zemljovid je zajedničko mjesto kolektivne svijesti otočana tih 20-ih godina 20. stoljeća, on visi na zidu svake kuće ili radnje, ne bi li im svijet postao bliži i »svjetska zbivanja razumljivija «. ${ }^{75}$ Zemljovid prati sve selidbe pjesnikinjine obitelji i taj obiteljski, otočki, iznova se metaforički dovodi u vezu sa svijetom oca koji stoji na suprotnoj strani od svijeta majke, vanjski svijet nasuprot privatnom, svijetu doma, metonimijski izraženom motivom ognjišta:

»(...) jedan veliki, dobro uščuvan zidni zemljovid, što bi ga otac odmah prikačio na počasno mjesto; obično visoko iznad kuhinjskoga stola. Bliže prozoru, a

\footnotetext{
${ }^{71}$ Isto, 38.

${ }^{72}$ Isto, 47.

${ }^{73}$ Isto, 50-51.

${ }^{74}$ Isto, 42.

${ }^{75}$ Isto, 64.
} 
podalje od ognjišta, koje je bilo svijet za sebe - i ni prevrtljiva povijest ni ukleti zemljopis nisu ga se ni najmanje ticali dok god je na njemu stajao gospodstveni lonac i dok je u kući bilo žigica da se pod njim zapali vatru. ${ }^{76}$

Zemljovid se jednim dijelom očituje kao metafora olabavljenih, hibridnih kolektivnih identiteta, ${ }^{77}$ a s druge strane kao ponekad jedina čvrsta točka konstruiranja autoričina sebstva u stalnim promjenama fizičkih prostora koje su je pratile:

»Ni mene, još kao djevojčicu, nije mimoišla ta slabost, ili bolje strast, prema zemljovidu kao postojanom životnom pratiocu, koji te iznevjeruje, ne svojom voljom, jedino kod nestanka starih država i nastanka novih, a to je uvijek praćeno promjenom onih markantno iščrčkanih vijuga, oko kojih plazi - pod neuglednim grmuljcima - tiha i neurastenično zlovoljna samosvijest državnih granica. ${ }^{78}$

Zemljovid Dalmacije predstavlja autoričinu osobnu identitetsku obilježenost zavičajem i duhovnu vezu s nestalim bratom koji joj je zemljovid ostavio na rastanku. Ranije spomenuta misao o suprotstavljenosti zbilje i unutrašnjeg svijeta pjesnikinje, prikazana je obrnutim odnosom fizičkog propadanja boja na zemljovidu i istodobnim jačanjem čežnje za zavičajem i bratom:

»(...) vrlo slikovitu kartu naše istočne obale Jadranskoga mora; mora koje je tu, meni s desna, ničijim pogledima podastrto osim mojim, isprva odisalo modrom svježinom galice i zelenilom limunova lišća (...) da bi potom, iz godine u godinu, ta modrina postepeno blijedila i prekrivala se mrenom zaborava sve to sivljom, što je moja žud za tim lijepim plavim Jadranom postajala gorčom i žarčom. No, blijedio s njime nije i besani bratov lik, a ni spomen na kobni rastanak, kada mi ju je u amanet ostavio, zaputivši se put Ivanje Rijeke... « ${ }^{79}$

Zavičajni prostor naglašeno je i na više mjesta utkan $u$ autoričin osobni identitet, a tijekom života često jedinu vezu s njime ostvaruje putem točaka na zemljopisnoj karti:

»(...) koji od dva na ovoj manjoj zemljopisnoj karti crnim točkama obilježena grada glasnije me dozivlje - Split ili Šibenik? Šum čijih borova jače me razdire - Marjana ili Šubićevca? Koji me val u mašti zapljuskuje ljekovitije - onaj blag, šoltanski, ili neutaživ i buntovan zlarinski? «80

Zemljovid Bugarske također je bitna metafora autoričina sebstva. Ona Bugarsku naziva »drugom domovinom«, a ključna odrednica ovog dijela autobiografije u dokumentarnom smislu je brak s Bugarinom, koji je propao iz

\footnotetext{
${ }^{76}$ Isto, 65.

${ }^{77}$ Ovisno o vladajućoj društvenoj ideologiji, jedan se zemljovid stavlja na zid, a drugi sakriva. Politički neutralan zemljovid pokazuje samo brda i doline. Otac je taj koji stavlja podobne i sakriva nepodobne zemljovide (usp. isto, 67).

${ }^{78}$ Isto, 65.

${ }^{79}$ Isto, 66.

${ }^{80}$ Isto, 89.
} 
političkih razloga i bio popraćen montiranim sudskim procesima, te iskustvo novog geografskog prostora s kojim se emotivno povezala i poistovjetila:

»(...) raskrstivši po sili politike, nakon ulaska sovjetskih trupa u Prag u kolovozu 1967. is tom mojom 'drugom domovinom' kao is mužem Ljubenom Žekovim. Tu neveliku zemljopisnu kartu države Bugarske nalijepila sam na zid, iznad neupotrebljiva plinskog štednjaka, pa sjela ondje i u nju dugo, rezignirano gledala (...) Opraštala sam se tako, bez riječi, i od lijepoga srcu mi priraslog Dunava na sjeveru te zemlje, od Silistre pa do Vidina uzduž rumunjske granice (...) ali i od još draže mi Varne i Sozopola na istoku, od krcato nesređenih uspomena i nedovršenih strofa zlatnopješčane crnomorske obale... « ${ }^{81}$

Zemljovid je jedna od triju mladenačkih strasti koja povezuje Vesnina nestaloga brata Mirka i Adnana, mladića iz Sirije i njezine velike ljubavi u poznim godinama:

»Mirko i Adnan - Hrvat i Sirijac - ne samo da bjehu nalik jedan drugome kao jaje jajetu, nego su ih resile i tri iste velike mladenačke strasti: nogometna lopta, bijeg od kuće i zemljovid. ${ }^{82}$

I Adnanov je zemljovid svijeta metaforički upisan u sebstvo autorice:

»(...) od Jeniseja do Sydneya i od Havaja do Palagruže; od južnosirijske škorpionu posvećene Acrabe, gdje se je on rodio u 'strijelcu' 1958. godine, pa do s Petrom Kružićem proslavljene tvrđave Klisa, pod kojom se je u srpnju godine 1920. rodio moj u grotlu ratnog meteža nestao brat. «83

»Sjetih se prvog našeg susreta: prvog poljupca očima (...) prvog nježnog dodira te muške bogodane ruke, koja me je u ovom širokom zbunjujućem, meridijanima i paralelama grubo opšivenom svijetu tražila i pronašla.. ${ }^{84}$

Autorica definira svoje sebstvo u cijelosti metaforom zemljovida:

»(...) jer kome da se ispovjedi vidjelac zemlje nego zemljovidu, od koga putnik savjet da potraži nego od puta, s kime beskućnik prag kućni da podijeli - nego s drugoga beskućnika sjenom.... ${ }^{85}$

Njezina je sudbina upisana u zemljovid (- »Znaš li da su Zlarin i Zagreb, nevjerojatno, oboje na istome meridijanu, šesnaestom?»«6).

I još više - zemljovid, taj zapis, slika i konstrukt stvarnog prostora, u pjesnikinjinoj mašti postaje oživljena metafora, svojevrsna pukotina u stvarnom vremenu i prostoru, koja joj u poetskom zanosu dopušta da fizički dotiče prostore zavičaja i sjećanja na brata što su, jedno s drugim, neizbrisivo povezani:

\footnotetext{
${ }^{81}$ Isto, 72.

${ }^{82}$ Isto, 84-85.

${ }^{83}$ Isto, 84 .

${ }^{84}$ Isto, 212-213.

${ }^{85}$ Isto, 89.

${ }^{86}$ Isto, 274.
} 
»(...) prstom sam išla sve po istom meridijanu na jug, uz rub krivudave obale toliko se uživivši u moje subverzivno prikradanje moru, da sam u jednom trenu osjetila kako me je nešto gricnulo za kažiprst. Povukla sam ruku. Na plavetnilu morske plohe mala brkata morska kozica, prozirna kao kristal i brza poput djetinjega oka (...) sve dok nije (...) dolutala ravno u bijelu platnenu kapu, koju je okrenutu naopačke držao objema rukama brat Mirko, polugol i mršav, sav naježen od kupanja u listopadu $(. ..) \ll^{87}$

Ipak, svijest o tome da slika nikada u potpunosti ne može zamijeniti stvarni prostor, kao što ni fotografija ne zamjenjuje osobu, a konačno, ni poezija život, stalno je prisutna:

»Da, ono se pred mojim očima prostro otok na kome sam se rodila (...) Ako je to onaj sa zemljovida u Adnanovoj sobi, onda smo moja fotografija u novinama i ja jedno te isto. Sva pomagala u životu pomalo nam lažu, njihova svrsishodnost uzima za sebe danak na koji se navikavamo kao na starenje i bolest. « ${ }^{88}$

\section{d) Vreće života}

Osim vlastite poezije kao metafore sebstva, te muškog kišobrana i zemljovida, sljedeća metafora u istoj funkciji je vreća, i to 40 vreća punih predmeta koji predstavljaju sav život pjesnikinje.

»Kaos? Da. Kaos moje sobe i kaos kozmosa: moj život u četrdeset vreća! Nije li to jedan isti zakon entropije? Krik rastuće jezgre vremena? Poezija golog prostora? Punjenje nebeskih tijela dušama? Nezaustavljivost mene u drugima. Drugih $u$ meni. Naš ljudski život u četrdeset milijardi ispražnjenih vreća za otpad. ${ }^{89}$ »To piše u tvojem davnom intervjuu 'Kani'! Trinaesta vreća desno u tvojoj sobi, ako želiš znati! ${ }^{90}$

Metafora vreće kod Vesne Parun uspostavlja izravne značenjske veze s općom simbolikom toga predmeta ${ }^{91}$ i popratnog broja $40 .{ }^{92}$ Međutim, tih 40 vreća

${ }^{87}$ Isto, 90 .

${ }^{88}$ Isto, 221.

${ }^{89}$ Isto, 143 .

${ }^{90}$ Isto, 335.

${ }^{91}$ Vreća je u tom smislu označena kao mjesto na kojem se čuva princip života, uz očitu konotaciju spasenja. Rječnik simbola navodi pjesmu psalmista iz kumranskih tekstova: Zahvaljujem ti, o Gospode!/Jer ti si dušu moju stavio u vrećicu živih/i zaštitio si me/od svih zamki ponora (J. CHEVALIER - A. GHEERBRANT, Rječnik simbola. Mitovi, sni, običaji, geste, oblici, likovi, boje, brojevi, Zagreb, Nakladni zavod Matice hrvatske, 1989, 765-766).

${ }^{92}$ Četrdeset je broj pripreme, kušnje ili kazne (40 dana lutanja pustinjom, 40 dana kiše u općem potopu, 40 dana Isusovih iskušenja i 40 sati boravka u grobu nakon kojih je uskrsnuo, itd.). Biblijski pisci njome označavaju glavna zbivanja u povijesti spasenja i uzastopne Božje intervencije. To je broj koji označava završetak jednog ciklusa koji ne teži ponavljanju, nego radikalnoj promjeni, prijelazu na drugu djelatnu i životnu razinu. U pogrebnim obredima mnogih naroda 40 je dana potrebno da bi se pogrebni ostatci posve oslobodili od svega što je živo u tijelu, od onoga najsuptilnijeg, svih svojih duša. Običaj četrdesetnice potječe od vjerovanja da broj 40 označuje jedan životni ciklus (Chevalier-Gheerbrandt, nav. dj., 90). 
su prije svega duboko osobni životni simbol za koji će autorica, tumačeći naslov svoje autobiografije $u$ jednom intervjuu reći:

»Taj grdi naslov podarih joj u vrijeme kad sam još imala podosta snage za humor nad vlastitim porazima, oličenim u tih 40 vreća koje su stvarne. Sada se one prazne, jedna po jedna, mileći kroz moju bijelu pustinju poput mravlje pogrebne povorke. Krivulja neostvarenih seoba. Zatvorenih putova. Bile su nažalost samo proročanski znak, prethodnica velikog sveopćeg egzodusa, tragika antidoma. Oko njih okrenulo se uz štropot nebo i zemlja. Nekoliko njih još je tu. One su ostale nepomične. Kao karjatide. Vreće ispunjene kamenjem života. Vreće ljubavi. Moj jedini skupocjeni kućni namještaj. Mrzim ga.«93

Iz zbirke Ja koja imam nevinije ruke (2009.) doznajemo, primjerice, da je u jednoj od njih Vesna pronašla prvi sonet koji je napisala u životu (1938., Susret u julu), po odlasku P. B., Boljanina, a za taj susret kaže da je bio fatalan i tragičan. Sonet je dugo bio izgubljen, a Vesna ga je pronašla $u$ »krasnopisu na djevičanskom listu papira «. ${ }^{94}$ Metafora vreće tako se otkriva u svojoj uskoj vezi s poezijom kao metaforom sebstva, što je moguće iščitati i u autobiografskim tekstovima (ili takvim dijelovima drugih tekstova, npr. predgovora koje je pisala) izvan okvira zbirke Noć za pakost. ${ }^{95}$

Međutim, i čitavo ljudsko životno iskustvo, ne samo Vesnino i ne samo ono čiji su artefakti spremljeni u njezinih stvarnih 40 vreća, iskazano je istom metaforom:

»Ne možeš naprosto sve to što ti život iz svojih turobnih vreća $u$ tebe saspe samljeti na brzinu i pospremiti u skladišta iskustva, već ionako krcata do vrha. Vreće se stalno množe i iskustva narastaju, a pretijesna skladišta postanu neuporabljiva, i napušta ih većina na polovici životnog puta.«96

Zanimljivo je da, kao što autobiografska protagonistkinja preuzima identitet »muškog kišobrana«, tako Adnan preuzima taj dio njezina identiteta koji je iskazan metaforom » 40 vreća«:

»Uostalom, što da budem liječnik? Pljačkat ću u pustinji karavane s vrećama soli - točno četrdeset vreća, jer to je brojka koja označava čovjeka, samog, usred zaglušne pustoši života.«"97

\footnotetext{
${ }^{93}$ Parun, Ja koja imam nevinije ruke..., 313. Riječ je o intervjuu s Denisom Derkom u Večernjem listu 1992. godine koji je ušao u zbirku Začarana čarobnica(1993.) i Ja koja imam nevinije ruke (2009.).

${ }^{94}$ Parun, Ja koja imam nevinije ruke..., 15.

${ }^{95}$ Usp. npr. predgovor zbirci Ja koja imam nevinije ruke (2009.) pod naslovom Od kroatozapadnjačke reakcionarke do jugobalkanske nostalgičarke navodi: »Ne znam jesam li ja prvi hrvatski Ali-baba, koji je od sveg blaga u svojoj špilji probrao ono što smatra ponajboljim, pa strpao sve to u jednu vreću i podbovši konjića odjezdio na sajam knjiga (Parun, isto, 19).

${ }^{96}$ Parun, Noć za pakost..., 284.

${ }^{97}$ Isto, 336.
} 


\section{Zaključak}

$\mathrm{Na}$ temelju analize metafora koje izriču sebstvo autodijegetskog pripovjedača dokazuje se jedinstvenost modela stvaranja autobiografskog diskursa Vesne Parun u hrvatskoj književnosti 20. stoljeća. Metafore sebstva u autobiografskom diskursu ove književnice uspostavljaju odnos i proširuju svoja značenja najprije na iskustva života bližnjih, koji su također postali protagonisti samoizricanja pripovjedača, a zatim, sukladno teorijama koje su bile razmatrane na početku rada (poglavito J. Olneya i P. Ricœura), na opće iskustvo bivanja čovjekom, što i jest u u temelju autobiografizma. Osim što naglašeno stvara odmak od pukog dokumentarnog prenošenja zbiljskih činjenica iz svoga života, autorica samu književnost predstavlja kao ključnu metafora svoga sebstva, čime se isti taj diskurs čitatelju otkriva kao izrazito (auto)metatekstualan.

S književnošću kao metaforom povezana je metafora muškog (očeva) kišobrana kao svjesno izabranog znaka vlastite različitosti. Kako i svoju poeziju stvara pod muškim kišobranom, njegov se metaforički potencijal može usporediti s metaforom »vlastite sobe«, koja u tradiciji tzv. ženskog pisma označava pravo žene na vlastitu književnu kreaciju i upisivanje ženskog iskustva u književni kanon. I zemljovid, kao zapis, slika i konstrukt stvarnog prostora, postaje oživljena metafora, svojevrsna pukotina u stvarnom vremenu i prostoru, koja pjesnikinji dopušta da fizički dotiče prostore zavičaja i sjećanja na bliske osobe (brata, ljubavnika).

Četvrta metafora, 40 vreća, također se otkriva u uskoj vezi s književnošću kao metaforom sebstva, budući da te vreće kriju Vesnine književne artefakte. Osim što su na taj način riznica pjesnikinjine vlastitosti, služeći se simboličkim potencijalom predmeta (vreće) i broja (40), književnica u tu metaforu upisuje čitavo ljudsko životno iskustvo, ne samo vlastito i ne samo književno. Analizom svih nabrojenih metafora sebstva kod Vesne Parun dolazi se do zaključka da iskazom o sebi autorica donosi i iskaz o drugome; »ja « i drugi poistovjećeni su činom autobiografskog samoizricanja i svakog pojedinačnog čitanja, a čitava zbirka Noć za pakost podcrtava ovaj kompleksan odnos posljednjom rečenicom:

»Ljubav je zemljovid duše. Moj zemljovid. Bože, ne otimaj mi ga! «88

${ }^{98}$ Isto, 340 . 


\section{Kornelija Kuvač-Levačićs \\ Metaphors of the Self in the Autobiographical Discourse of Vesna Parun}

Summary

By using the concept of the Self as the human personality in its totality, as defined by Carl Gustav Jung and furthered by P. Ricœur (the theory of narrative identity, the Self defined as an identity constructed by narrative configuration, the dialectics of the discovery of the other in one's own Self and one's own Self in the Other), this work will focus in the analysis of metaphors which express the Self of the auto-diegetic narrator as can be found in the autobiographical discourse of Vesna Parun. The corpus of this research is to be found in selected texts from her volume Noć za pakost. Moj život u 40 vreća (2001). From the first chapter of this volume [which consists of the following works of autobiography and essays: Poljubac života (1993), Do zalaska sunca hodajući za kamilicom (1958), Pod muškim kišobranom (1986)] the reader comes to realise that, for this author, the writing of autobiography is itself a problem of self-expression and that she had constantly deferred it, while, on the other hand, feeling a great compulsion from within to do so. This sense of paradox finds its reflection in some of the constitutive elements which can be found in her autobiographical discourse. In the relationship between literature and reality, which is something which the genre of autobiography questions in its own way, the author noticeably distances herself from the mere documentary transmission of factual information from her life. A reflection of this can be seen in the negation of a strict chronology of events and confessions, as she makes recourse to a technique which uses collage and appears fragmentary; furthermore, here prose here has a lyrical quality, negating »metaphor as a literary device« and transforming it into »literature as metaphor «. The autobiographical prose of Vesna Parun is especially dense with metaphor, and it can be concluded that it expresses her Self. Attention is directed here to three metaphors in particular - the umbrella, which can be both »masculine« and »feminine«, a map of the world, on the wall of every house in Vesna's community, as well the sack, which is followed by the symbolic number 40 , as many in which she could fill her life in. Besides the metaphors mentioned here, what will be proposed here is that in the autobiographical discourse of Vesna Parun literature itself is presented as metaphor of her Self, appearing to the reader as significantly (auto)meta-textual.

Keywords: self, autobiographical discourse, narrative identity, Vesna Parun, metaphor, umbrella, map of the world, sack.

(na engl. prev. Krešimir Vunić)

\footnotetext{
* Kornelija Kuvač-Levačić, PhD, Asisstant Professor, Division of Croatian Language and Literature, Department of Croatian and Slavic Studies, University of Zadar; Address: Obala kralja Petra Krešimira IV., HR-23000 Zadar, Croatia; E-mail: klevac@unizd.hr.
} 